\title{
Profesor Adam Stalony Dobrzański - mistrz i nauczyciel Jerzego Nowosielskiego
}

\author{
Ks. Jarosław Szmajda \\ jszmajda@poczta.onet.pl
}

Rev. Jarosław Szmajda, Professor Adam Stalony-Dobrzański - the Master and the Teacher of Jerzy Nowosielski, Elpis, 16 2014: 191-200.

\begin{abstract}
When analyzing the history of Polish religious art of the XX century, we can affirm that the entire creative work of Adam Stalony-Dobrzański, professor at Kraków Academy of Fine Arts, remains in the shadow of the artistic output of Prof. Jerzy Nowosielski, his student and follower.

Jerzy Nowosielski had a noticeable impact on the interest in the problems of the sacred in modern painting. The follower of Prof. Adam Stalony-Dobrzański was inspired by the art and the spirituality of Eastern Christianity. Prof. Jerzy Nowosielski filled some kind of a void in Polish religious art in the period of its evident crisis. Prof. Jerzy Nowosielski together with Prof. Adam Stalony-Dobrzański created polychrome frescoes of numerous religious buildings. The styling and the artistic accomplishments of Prof. Adam Stalony-Dobrzański are unknown for the wide audience which makes an evident gap in the history of Polish art. Polychrome frescoes and stained glass windows can be seen in interiors of Catholic, Orthodox, and Protestant temples. The creative work of the Kraków artist is an example of the great and highly authentic vision of the sacred, which was stronger than communist censorship.

The concept of Adam Stalony-Dobrzański's art is not based on his theoretical conclusions but only on the analysis of correspondence of the artist with the then Metropolitan Archbishop of Kraków Karol Wojtyła - now St. Pope JohnPaul II. The topic of their letters was the issues of modern art and religious art, in particular the attempt to define a way in which art should be developed to meet the current needs of the Church. In contrast to the master, Prof. Adam Stalony-Dobrzański, his follower Prof. Jerzy Nowosielski has left ample commentary on his artwork. Prof. Adam Stalony-Dobrzański was rather a practitioner than a theoretician. Thus the fact of how great an impact he had on the character and the artwork of Jerzy Nowosielski is puzzling. In the first half of the 1950s, the "master-student" relationship existed between artists, at least in Gródek, Jelenia Góra, Dojlidy, Warsaw and Grabarka. The link between the two artists were the East, Orthodox Christianity, the icon and openness to its modern forms and its bold combination with the experience of religious art. As for Poland, the artwork of Prof. Adam Stalony-Dobrzański and Prof. Jerzy Nowosielski are an integral part of the history of religious art of the $20^{\text {th }}$ century as well as the art of stained glass. Its impact lies in the core of such great interest in the icon in Poland.

The creative work of Prof. Adam Stalony-Dobrzański has so far remained in the shadow of the works of Prof. Jerzy Nowosielski. The biography and the creative achievements of Prof. Adam Stalony-Dobrzański merit detailed analysis and study. The question of its importance is raised in this article.
\end{abstract}

\begin{abstract}
Streszczenie: Dokonując analizy historii polskiej sztuki sakralnej XX w. można wysnuć stwierdzenie, iż całokształt twórczości prof. Adama Stalony-Dobrzańskiego - wykładowcy Akademii Sztuk Pięknych w Krakowie pozostaje w cieniu dorobku artystycznego jego studenta i późniejszego ucznia prof. Jerzego Nowosielskiego.

Zauważalny jest wpływ prof. Jerzego Nowosielskiego na zainteresowanie problemami sacrum w malarstwie współczesnym. Uczeń prof. Adama Stalony-Dobrzańskiego czerpał inspiracje z sztuki i duchowości chrześcijańskiego Wschodu. Prof. Jerzy Nowosielski swoją twórczością wypełnił pewnego rodzaju pustkę artystyczną w okresie wyraźnego kryzysu sztuki sakralnej w Polsce. Prof. Jerzy Nowosielski współpracował z prof. Adamem Stalony-Dobrzańskim przy wykonywaniu wielu polichromii obiektów sakralnych. Sylwetka i dokonania twórcze prof. Adama Stalony-Dobrzańskiego, nie są znane szerszemu kręgu odbiorców co wyraźnie stanowi lukę w polskiej historii sztuki. Polichromie i witraże prof. Dobrzańskiego widoczne są we wnętrzach świątyń katolickich, prawosławnych i protestanckich. Twórczość krakowskiego artysty jest przykładem wielkiej i niezwykle autentycznej wizji sacrum, wizji silniejszej niż komunistyczna cenzura.

Koncepcja sztuki Adama Stalony-Dobrzańskiego nie jest podparta jego teoretycznymi rozważaniami a jedynie analizą korespondencji jaką krakowski artysta prowadził z ówczesnym metropolitą krakowskim, arcybiskupem Karolem Wojtyłą - obecnie kanonizowanym Janem Pawłem II. Tematem ich rozmów były zagadnienia związane ze stanem współczesnej sztuki, w szczególności sakralnej oraz próba określenia kierunku, w którym powinien nastąpić rozwój sztuki, by spełniać rzeczywistą potrzebę Kościoła. W przeciwieństwie do mistrza prof. Adama Stalony-Dobrzańskiego jego uczeń prof. Jerzy Nowosielski, pozostawił bogaty komentarz do swojej twórczości. Prof. Adam Stalony-Dobrzański był bardziej praktykiem niż teoretykiem. Zastanawiającym jest więc, jak wielki miał wpływ na osobę i twórczość Jerzego Nowosielskiego. W pierwszej połowie lat 50. artyści współpracowali bowiem w relacji mistrz - uczeń, chociażby w Gródku, Jeleniej Górze, Dojlidach, Warszawie czy Grabarce. Ogniwem łączącym obydwu artystów jest Wschód, prawosławie i ikona oraz otwartość na współczesną formę i odważne połączenie jej z doświadczeniem sztuki cerkiewnej. Na gruncie polskim bez prof. Adama Stalony-Dobrzańskiego i prof. Jerzego Nowosielskiego - mistrza i ucznia historia sztuki sakralnej XX wieku pozostaje uboższa o niezwykle ważny element, który leży u podstaw tak szerokiego zainteresowania ikoną w Polsce. Twórczość prof. Adama Stalony-Dobrzańskiego, pozostawała dotychczas w cieniu dzieł prof. Jerzego Nowosielskiego. Biografia i dokonania twórcze prof. Adama Stalony-Dobrzańskiego zasługują na szczegółową analizę i poznanie, o czym traktuje artykuł.
\end{abstract}

Keywords: Adam Stalony-Dobrzański, Jerzy Nowosielski, Jan Pawlicki, Polish iconography, theology of the icon, polychrome, stained glass, mosaic, Kraków Academy of Fine Arts, Przemków, Grabarka, Jelenia Góra, Wrocław, Warsaw, Dojlidy

Słowa kluczowe: Adam Stalony-Dobrzański, Jerzy Nowosielski, Jan Pawlicki, ikonografia polska, teologia ikony, polichromia, witraż, mozaika, Akademia Sztuk Pięknych w Krakowie, Przemków, Grabarka, Jelenia Góra, Wrocław, Warszawa, Dojlidy

\section{Biografia}

Adam Stalony-Dobrzański urodził się 19 listopada 1904 roku we wsi Mienie ${ }^{1}$, w powiecie sośnickim,

Wieś Miena położona jest na północny-wschód od Kijowa. w guberni czernihowskiej, na terenie dzisiejszej Ukrainy. Był najstarszym synem Feliksa Stalony-Dobrzańskiego i Anny z domu Kowalenko. Ojciec, katolik, wnuk zesłanego na Syberię uczestnika powstania styczniowego (1863), piastował stanowisko sędziego śledczego w Czernihowie. Matka, Ukrainka, pochodziła 
z kupieckiej rodziny o staroobrzędowej tradycji wyznaniowej ${ }^{2}$.

Rodzice Adama Stalony-Dobrzańskiego wzięli ślub w cerkwi. Matka z miłości do męża, zaniosła pierworodnego syna do kościoła. Ojciec dumny i wdzięczny wypełnił stosowne dokumenty. Jednak ten ostatni dokument, wymóg zrzeczenia się przez prawosławną matkę praw do uczestnictwa w duchowym wychowaniu syna, zmienił losy małego Adama. Ojciec, honorowy Polak-katolik, w jednym momencie decyduje o chrzcie dziecka w cerkwi, gdzie też chrzci wszystkie swoje dzieci3: córkę Aleutynę Honoratę (1906-1978) - rusycystkę i nauczycielkę wychowania fizycznego, oraz syna Seweryna (1908-1985) - prawnika i adwo$\mathrm{kata}^{4}$. Przyszły artysta był więc człowiekiem wychowanym w świecie dwóch kultur: polsko-katolickiej i ukraińsko-staroobrzędowej. W rodzinie Dobrzańskich przechowywane były tradycje rycerstwa spod Grunwaldu, na którego to polach w 1410 roku, hufce Dobrzańskich za męstwo w walce, otrzymały przydomki szlacheckie Stalony i Hubal ${ }^{5}$.

Od około 1906 roku rodzina Stalony-Dobrzańskich zamieszkała w powiatowym mieście Czerykowa, w guberni mohylewskiej. W 1913 roku Adam Stalony-Dobrzański złożył egzamin wstępny do rosyjskiego gimnazjum humanistycznego, w którym ukończył tylko 5 klas. Naukę przerwała mu niestety wojna i rewolucja ${ }^{6}$.

W roku 1917 trzynastoletni Adam wraz z rodzicami i rodzeństwem opuścił swój dom. Znalazł się ktoś, kto w zamian za wóz i parę koni, podjął się dowiezienia ich do oddalonej o ponad sto wiorst stacji kolejowej. Tak zakończyło się jego dzieciństwo ${ }^{7}$. Po długiej podróży dotarł z rodziną do Pryłuk koło Połtawy, do swych dziadków ze strony matki - Kowalenków ${ }^{8}$. Od 1920 roku aby zdobyć żywność dla rodziny pracował fizycznie jako robotnik rolny i transportowy, przy pasaniu koni, wyrębie i zwózce drzewa, kopaniu torfu, ładowaniu wagonów, ${ }^{9}$. Już wówczas nadwyrężył sobie serce. W tym czasie rozpoczął studia malarskie pod kierunkiem dwóch rosyjskich malarzy M. Chitagurowa i A. W. Skałłona ${ }^{10}$. Spotkania odbywały się wieczorami. Przy świetle lampy naftowej malował na zamówienie martwą naturę oraz szyldy, plansze, portrety i pokoje ${ }^{11}$.

W 1923 roku miało miejsce przykre zdarzenie, które zaważyło na dalszych losach artysty - został pogryziony przez wściekłego psa. W wyniku tego trafił do szpitala w Kijowie.

\footnotetext{
2 E. Dwornik-Gutowska, Stalony-Dobrzański Adam, Polski Słownik Biograficzny, Tom XLI, Warszawa-Kraków 2002, s. 497.

3 Суt. zа Я. Павлицький, Адам Сталони Добжанський або Сотворіння Світла, [в:] Культура, Нр. 43, 2009, с. 13.

4 E. Dwornik-Gutowska, dz. cyt., s. 497.

J. Pawlicki, Stworzenie światła: witraże Adama Stalony-Dobrzańskiego, [w:] Zabytki, Nr 7(22), Warszawa 2007, s. 13.

6 Archiwum Akademii Sztuk Pięknych w Krakowie, akta osobowe prof. Adama Stalony-Dobrzańskiego, 1947-1975, nr teczki 650/274.

Cyt. za A. Stalony-Dobrzańska, Błękit, [w:] Wiadomości PAKP, nr 4, Warszawa 1979, s. 122

8 E. Dwornik-Gutowska, dz. cyt., s. 497.

9 AASP w Krakowie, nr teczki 650/1.

10 Wystawa witraży. Adam Stalony-Dobrzański 1950-1960, Kraków XII 1960/I 1961, s.2.

11 AASP w Krakowie, nr teczki 650/264; por. A. Stalony-Dobrzańska, dz. cyt. s. 124 .
}

Po wyjściu odszukał krewną Felę Jankowską, która wyjeżdżała właśnie do Polski. Gdy dotarła do kraju, poprosiła dwóch żyjących stryjów o pomoc w załatwieniu zapotrzebowania repatriacyjnego dla rodziny Stalony-Dobrzańskich. Po paru miesiącach oczekiwania przysłali im niezbędne do wyjazdu dokumenty. W marcu tegoż roku razem z rodzicami i rodzeństwem repatriował do Polski ${ }^{12}$. Z Dorohuska pod kontrolą policji odstawiono ich do Warszawy, na Powązki do więzienia. Stryj Antoni, profesor Politechniki Warszawskiej, który wystarał się i wysłał im przez polski konsulat w Charkowie dokumenty repatriacyjne, przychodził aż dwa razy, by udowodnić ich tożsamość. To spowodowało uwolnienie uchodźców. Po paru dniach udali się do drugiego stryja Ksawerego, do Tuczna. Niedługo potem ojciec otrzymał nominację na sędziego śledczego w Miechowie niedaleko Krakowa. Zamieszkali w jednym, ale za to dużym pokoju w budynku sądu ${ }^{13}$.

Adam Stalony-Dobrzański kontynuował przerwaną przez wojnę i rewolucję naukę w miechowskim gimnazjum męskim. Już wówczas pedagodzy dostrzegli talent młodego Adama, który wyróżniał się w rysunkach. Wykonywał wówczas wiele prac dekoracyjnych dla szkoły, $m$. in. polichromię w szkolnej auli. Rok 1927 był dla niego szczególny. Z jednej strony radość, gdyż wstępuje w dorosłość, zdaje egzamin dojrzałości w miechowskim gimnazjum i dostaje się na studia. Umiera mu jednak ojciec. Matka z rodzeństwem przenosi się w roku następnym do Krakowa. Wszyscy zamieszkali przy ul. Kazimierza Wielkiego $64^{14}$.

W Akademii Sztuk Pięknych w Krakowie studiował $\mathrm{w}$ pracowniach wielkich artystów, profesorów lat trzydziestych: Władysława Jarockiego (1927-28), Fryderyka Pautscha(1928-30), Ignacego Pieńkowskiego (1930-33). Korzystał ponadto z nauk Xawerego Dunikowskiego, Jana Wojnarskiego i Józefa Mehoffera ${ }^{15}$, którego stał się chyba najbardziej godnym następcą, zwłaszcza w zakresie sztuki witrażu,. Nie był jednak jego naśladowcą, demonstrował własny, wyrazisty styl. Na krystalizację tego stylu wpływ miała nie tylko krakowska Akademia Sztuk Pięknych, lecz także sztuka w Krakowie, panujące w Europie trendy artystyczne, jak również korzenie rodzinne, bliskie kontakty w dzieciństwie i wczesnej młodości z religią i kulturą budowaną na bizantyńskiej tradycji. Witrażownictwo było koronną gałęzią w twórczości Stalony-Dobrzańskiego. Na tę drogę wkroczył już w dojrzałym wieku. W latach 1950-1956 z polecenia Pani Izabeli Żeleńskiej, właścicielki najsłynniejszej krakowskiej pracowni witraży - Zakładu Żeleńskich, w którym swe prace realizowali Stanisław Wyspiański i Józef Mehoffer wykonał witraże do kościoła w Trzebownisku koło Rzeszowa, co ostatecznie ukierunkowało zainteresowania artysty witrażem ${ }^{16}$.

\footnotetext{
12 E. Dwornik-Gutowska, dz. cyt., s. 497; por. A. Stalony-Dobrzańska, dz. cyt., s. 125

13 Tamże s. 126.

14 E. Dwornik-Gutowska, dz. cyt., s. 497.

15 Katalog wystawy kartonów witraży Adama Stalony-Dobrzańskiego [1950-1956], Towarzystwo Przyjaciół Sztuk Pięknych, Kraków 1957, s. 2; por. T. Dobrowolski, Nowoczesne malarstwo polskie, tom III, WrocławWarszawa-Kraków 1964, s. 339.

16 Dobrzański Adam Stalony, za http://pracownia.michalowo.eu/znaniludzie-15 [16.06.2014].
} 
W trakcie studiów w Akademii Sztuk Pięknych w Krakowie szczególnie w pamięci młodego studenta zapisał się wykładowca liternictwa i grafiki użytkowej Ludwik Gardowski, z którym łączyła go później wieloletnia współpra$\mathrm{Ca}^{17}$. Studia upłynęły artyście w atmosferze mistyki Młodej Polski. Uczelnię ukończył w roku 1932 z wynikiem bardzo dobrym. Złożył dodatkowy egzamin w zakresie nauczania rysunków przed komisją przy ASP w Krakowie ${ }^{18}$.

W roku 1935 Adam Stalony-Dobrzański wstąpił w związek małżeński w obrządku rzymskokatolickim z Anną Danutą Nowakowską urodzoną w Wolbromiu. Urodziło im się troje dzieci: Anna (1936-1991), zamężna Pawlicka, etnograf, pracownik UMCS w Lublinie i Biblioteki PAN w Krakowie; Andrzej (ur. 1939), aktor-lalkarz w Teatrze Lalki i maski „Groteska” w Krakowie ${ }^{19}$ i Katarzyna (ur. 1944), matematyczka, nauczycielka ${ }^{20}$.

We wrześniu 1939 roku wybuchła wojna. Pierwsze lata okupacji niemieckiej profesor spędził w Krakowie. Po śmierci matki 5 grudnia 1942 roku przeniósł się do wsi Goszyce koło Proszowic, gdzie od roku 1939 mieszkała i była nauczycielką jego żona. Znalazł tam zatrudnienie jako nauczyciel rysunków i religii w szkole powszechnej ${ }^{21}$. Pod koniec wojny w styczniu 1945 roku został postawiony przed niemieckim plutonem egzekucyjnym. Zarzucono mu, że jako repatriant ze wschodu był sowieckim szpiegiem. W pewien styczniowy poranek doświadczył cudu. Żołnierze Wermachtu, składając się do strzału zobaczyli nacierające sowieckie czołgi i uciekli w popłochu ${ }^{22}$. Wyzwolenie i życie, w dosłownym tego słowa znaczeniu, zawdzięczył żołnierzom armii radzieckiej. W roku 1945 wrócił wraz z rodziną do Krakowa, otrzymał mieszkanie w jednym z domów przeznaczonych dla artystów plastyków przy ul. Lea $23 \mathrm{~A}$ i mieszkał tam do końca życia ${ }^{23}$.

Artysta był wykładowcą w Liceum Sztuk Plastycznych $^{24}$. Jesienią 1945 roku został zatrudniony na Wydziale Architektury przy Akademii Górniczo-Hutniczej w Krakowie jako asystent Ludwika Gardowskiego. Z dniem 1 października 1947 został wykładowcą w Zakładzie Liternictwa Wydziału Grafiki Użytkowej Państwowej Wyższej Szkoły Sztuk Plastycznych (PWSSP), a następnie, po połączeniu w roku 1951 szkoły z Akademią Sztuk Pięknych, w Akademii Sztuk Plastycznych. W roku 1957 po przywróceniu uczelni dawnej nazwy - Akademia Sztuk Pięknych i jej reorganizacji, został mianowany docentem ${ }^{25}$. Od 1958 roku prowadził Katedrę, a następnie pracownię liternictwa na Wydziale Malarstwa i Grafiki. Liternictwo w kolejnych okresach obejmowało różne lata studiów i wydziały:Grafiki, Malarstwa, Architektury Wnętrz, Konserwacji, Sce-

\footnotetext{
7 AASP w Krakowie, nr teczki 650/242.

18 Tamże, nr teczki 650/274.

19 Nekrolog, Dziennik Polski, Nr 74, Kraków 1985, s. 4.

E. Dwornik-Gutowska, dz. cyt., s. 499.

Tamże s. 497

J. Pawlicki, art. cyt., s. 13.

23 E. Dwornik-Gutowska, dz. cyt., s. 497.

24 Wystawy jubileuszowe 150-lecia Akademii Sztuk Pięknych w Krakowie, Kraków 1969, s. 131

25 AASP w Krakowie, nr teczki 650/111.
}

nografii i Tkaniny ${ }^{26}$. Było wówczas katedrą międzywydziałową ${ }^{27}$. W latach 1966-1968 był prodziekanem wydziału i członkiem senatu $\mathrm{ASP}^{28}$.

W uznaniu zasług 20 listopada 1971 roku otrzymał nagrodą I-stopnia Ministra Kultury i Sztuki za szczególne osiągnięcia w dziedzinie pracy artystycznej i dydaktyczno -wychowawczej. 4 października 1973 roku został odznaczony Krzyżem Kawalerskim Orderu Odrodzenia Polski ${ }^{29}$. Za swoją pracę nagrodzony został ponadto Medalem X-lecia Polskiej Rzeczpospolitej Ludowej, Złotą Odznaką Związku Nauczycielstwa Polskiego oraz Złotą Odznaką Zasłużonego Działacza Frontu Jedności Narodowej ${ }^{30}$.

$\mathrm{Na}$ emeryturę przeszedł 20 września 1975 roku. Ze względu na swoje poglądy polityczne i religijne, mimo wielokrotnego zgłaszania przez senat Akademii Sztuk Pięknych, nigdy nie uzyskał stopnia profesora ${ }^{31}$.

Adam Stalony-Dobrzański zmarł 22 III 1985 w Krakowie $^{32}$. Artysta pochowany został na cmentarzu Rakowickim w grobowcu rodzinnym, dla którego sam zaprojektował nagrobek. Pośmiertnie w roku 1985 został odznaczony nagrodą im. błogosławionego brata Alberta. Jego prace zostały pokazane na wystawach: w Paryżu w roku 1989, we Wrocławiu w roku 1997- urządzonej z okazji Kongresu Eucharystycznego i w Kijowie w roku $2001^{33}$.

\section{Charakterystyka dokonań twórczych}

Adam Stalony-Dobrzański znany jest nie tylko jako malarz, grafik, witrażysta, liternik, konserwator dzieł sztuki, wykładowca Akademii Sztuk Pięknych w Krakowie, ale przede wszystkim jako artysta, który pozostawił po sobie ogromny dorobek życia. Jego polichromie i witraże do dzisiaj zdobią wnętrza wielu świątyń, stając się ich nierozerwalną częścią. Widoczna w nich twórczość Stalony-Dobrzańskiego $\mathrm{w}$ sposób bezpośredni wyrasta $\mathrm{z}$ tradycji Bizancjum. Jak mało kto wówczas w Polsce znał jego kanon, schemat, gest, patos, intymność i zawiłości protokolarne. Oczywiście bizantynizm Dobrzańskiego dochodzi w pełni do głosu w przypadku pracy w cerkwi, tam jednak, gdzie artysta projektuje dla kościołów łacińskich ulega pewnemu zanikowi ${ }^{34}$.

Dobrzański całe swoje życie poświęcił pracy artystycznej i pedagogicznej. Działalność artystyczną rozpoczął

\footnotetext{
Tamże, nr teczki 650/266.

27 Tamże, nr teczki 650/44.

28175 lat nauczania malarstwa, rzeźby i grafiki w krakowskiej ASP, Kraków 1994 s. 396.

29 AASP w Krakowie, nr teczki 650/40.

30 R. Marcinkowski, ks. bp, Kronika religijna. Śp. prof. Adam StalonyDobrzański [w:] Tygodnik Powszechny, Nr 14, Kraków 1985, s. 7.

31 E. Dwornik-Gutowska, dz. cyt., s. 497.

32 Doc. Adam Stalony-Dobrzański, [w:] Dziennik Polski, Nr 74, Kraków 1985, s. 5.

33 E. Dwornik-Gutowska, dz. cyt., s. 499.

34 T. Chrzanowski, Z krakowskich wystaw, [w:] Tygodnik Powszechny, Nr 15, Kraków 1961, s. 6.
} 
jeszcze przed wojną. Po wojnie rozwinął twórczość niemal we wszystkich dziedzinach plastycznych. Wykonane przez niego prace obejmuje wielką ilość pozycji, z których każda stanowi poważny dorobek artystyczny autora, zajmując równocześnie poważną pozycję $\mathrm{w}$ powojennym dorobku kultury narodowej. Oprócz wielu realizacji z zakresu nauczanego przedmiotu pozostawił po sobie wydawnictwa, albumy, plakaty, okładki, katalogi, tablice pamiątkowe, sztandary, odznaki. Brał udział w konsultacjach i komisjach wydawniczych, konkursach, wykonał wielką ilość dzieł z zakresu konserwacji zabytków malarstwa monumentalnego, witraży, projektów metaloplastyki i architektury ${ }^{35}$. Informacje o jego twórczości ukazywały się w prasie krajowej i zagranicznej. Na wystawach dorobku plastycznego prezentowano wszechstronny talent i bezsporne wartości artystyczne dzieł.

Wszechstronne zainteresowania i olbrzymie doświadczenie, powiązane z niezwykłą pasją pedagogiczną sprawiły, że nauczane przez niego liternictwo osiągnęło rangę przedmiotu artystycznego o monumentalnym znaczeniu dla wszystkich dziedzin twórczości plastycznej, niezależnie od ich funkcji. W swoim programie i sposobie ujęcia był kontynuatorem linii nadanej przez dawnego kierownika katedry prof. Ludwika Gardowskiego ${ }^{36}$. Dobrzański uznawany jest za jednego z twórców polskiej szkoły liternictwa. Był wybitnym specjalistą, tworzącym nowe koncepcje liternicze. Liternictwo było dla niego nie nauką pisania, ale problemem kompozycji plastycznej jaką jest sam symbol-litera.

Obserwował współzależność poszczególnych znaków w różnych układach tekstowych, współzależność formy litery i środków wykonania w materiale, powiązanie z elementami obrazowymi. Zagadnieniem pierwszoplanowym było dla niego współgranie formy plastycznej z treścią, jaką przekazać należy za pomocą znaków literowych. Uczył, wykorzystując przykłady historyczne. Wprowadził alfabet rosyjski jako równoległy przedmiot rozważań, gdyż prowadził poważne prace naukowe między innymi nad czcionkami rosyjskimi ${ }^{37}$. Pomocną okazała się znajomość języków obcych. Ze względu na swoje pochodzenie i wychowanie, w duchu staroobrzędowym, znał bardzo dobrze w mowie i piśmie język cerkiewno-słowiański, rosyjski i ukraiński. Natomiast na poziomie szkolnym francuski i łacinę. $\mathrm{W}$ pracy pedagogicznej przekazał studentom całą wiedzę o budowie litery, jej rozwoju historycznym, jej kształcie $\mathrm{w}$ zależności od epoki oraz powiązania $\mathrm{z}$ architekturą. Zakres poznania i działania litery rozszerzył do wielkiego zagadnienia. Zarówno zrozumienie charakteru litery klasycznej z jej wszystkimi prawami renesansowego myślenia, budową, logiką i ogólnymi prawami rządzących nią dawniej jak i obecnie. Taka logiczna metoda pracy artystycznej wiążąca dawne tradycje z nowymi wymaganiami była dobrą szkołą odpowiedzialności w sztuce polskiej. Wychował wielu pedagogów szkolnictwa artystycznego. Jego studentem był Jerzy Nowosielski ${ }^{38}$.

\footnotetext{
35 AASP w Krakowie, nr teczki 650/41.

36 Tamże, nr teczki 650/260.

37 Tamże, nr teczki 650/192.

38 Tamże, nr teczki 650/224.
}

Specjalnością, która zapewniła Adamowi Stalony-Dobrzańskiemu nazwisko i autorytet, był witraż. Jego dorobek $\mathrm{w}$ tym zakresie nabrał znaczenia wyjątkowego, ponieważ przerwał on zastój i stagnację w tej dziedzinie, trwającą od czasów Wyspiańskiego i Mehoffera. Dobrzański nawiązuje do tradycji starego witrażownictwa poprzez uwydatnianie konstrukcji i wbudowywanie zwarte kompozycji biblijnych w poszczególne podziały. Tam zaś, gdzie obraz zajmował więcej podziałów, ustawiał swe szklane układy według pionów i poziomów okiennej ramy. Dzięki owym rygorom konstrukcyjnym, artysta osiągnął efekty plastyczne zbliżone do nowoczesnej architektury. Witraż ze względu na swą specyfikę musi operować nowoczesnymi środkami plastycznymi: abstrakcyjnym ujęciem tematu, skrótem plastycznym, uproszczonym ornamentem, jak najdalej idącą umownością. Nie może być malarstwem iluzyjnym: wyraża świat wyłącznie przez relacje kompozycji szkła ze światłem. Witraż żyje dzięki światłu, a światło dzięki witrażowi ${ }^{39}$. Sam Dobrzański powiedział, iż dopiero na miejscu witraż montuje się w okna w żelazne sztaby i zamurowuje się. I dopiero wtedy chciałoby się przeprowadzić ostateczną korektę, gdy dzieło jest już w jakimś sensie nieosiągalne. W żadnej chyba innej dziedzinie sztuki odległość między projektem, a realizacją nie jest tak wielka. Trzeba mieć ogromną znajomość techniki, ogromne wyczucie architektury i sporo intuicji. Gotowy witraż, otwarty nagle na działanie zmiennego światła dnia, zaczyna żyć życiem zupełnie nowym, w pewnym sensie niezależnym od woli artysty ${ }^{40}$.

Witrażownictwo Dobrzańskiego wniosło ożywienie i przywróciło witrażowi w Polsce rangę artystyczną i rolę w służbie sakralnej. Godnym osobnego rozważania jest fakt wprowadzenia przez niego witraży w cerkwi. Żarliwość, talent, wiedza i bezkompromisowość artysty złożyły się u niego na szczerą wypowiedź artystyczną, a płynące z głębi przekonania przeżycie nadało jej piętno autentyzmu, nieczęste w wystrojach kościołów współczesnych. Kartony i witraże twórcy wprowadzają odbiorcę $\mathrm{w}$ nastrój misterium i czynią z niego jego uczestnika. Stąd siła oddziaływania witraży Dobrzańskiego na wszystkich wrażliwych odbiorców w świątyniach jak i poza nimi. Kompozycje witrażowe Dobrzańskiego pozostawały zawsze w związku $\mathrm{z}$ architekturą, do której zostały zaprojektowane, wynikały także z właściwości tworzywa, jakim jest szkło barwne, przeniknięte żywą zmiennością światła oraz ołów łączący szyby zamknięte $w$ żelazo i mur. Tym tworzywem operował Dobrzański z pełną znajomością i swobodą w dążeniu do wywołania potrzebnego nastroju i wyrazu poszczególnych okien, zależnie od przedstawianego tematu, miejsca w zespole architektonicznym i kontekście tematycznym. Istotną cechą jego kompozycji witrażowych była monumentalność. Powierzchnia okna pozostawała płaszczyzną dekoracyjną o określonej tonacji barwnej, różnej w różnych oknach i zespołach, zależnie od tematów i warunków oświetlenia danego wnętrza. Nieodłącznym elementem

\footnotetext{
39 P. Skrzynecki, Witraże w pałacu sztuki, [w:] Echo Krakowa, $\mathrm{Nr} 68$, Kraków 1957, s. 4.

40 T. Chrzanowski, art. cyt., s. 6.
} 
kompozycyjnym postaci, scen i symboli jest liternictwo. Liternicza koncepcja napisów stanowi dopełnienie grup figuralnych i jest ważnym elementem całości ${ }^{41}$.

W witrażach dostrzec należy twórcze pierwiastki, formę dojrzałą, zespolenie wszystkich szczegółów kompozycji, słów, tekstu równomierną płaszczyznę wzbogaconą działaniem barw. Są najbardziej samodzielnym osiągnięciem profesora w tej dziedzinie sztuki ${ }^{42}$.

Witraż jeszcze silniej wpływa na ukształtowanie charakteru wnętrza, aniżeli malowidła ścienne. Od jego koloru zależy ogólna tonacja wnętrza, on sam, spełniając równocześnie tę rolę co malarstwo, nieustannie przekształca się i zmienia zależnie od pory dnia i roku, zależnie od zmiany oświetlenia. Między innymi stąd trudność jego skomponowania, zwłaszcza kolorystycznego, tym bardziej, ze względu na fakt, że przepuszcza światło, a nie tylko je odbija. To właśnie narzuca pewne odrębne wymagania. Adam Stalony-Dobrzański dążył do połączenia tradycji, najlepiej odpowiadającej technice, z nowoczesnym ujęciem. Jego witraże całościowo dobrze skomponowane, ze słusznym wykorzystaniem podziału na kwatery, są bogato wypełnione tekstem, którego liternictwo łączy się z nim w jeden zespół. Przedstawienia, bardzo logicznie skomponowane, $\mathrm{z}$ dużą oszczędnością środków, mają coś wspólnego ze sztuką ludową, a równocześnie ze średniowieczem jak i ze współczesnymi dążeniami do syntezy i eliminacji zbędnych dla ogólnego wyrazu szczegółów. Całość traktowana jest zupełnie płasko bez jakiejkolwiek przestrzeni iluzjonistycznej co pozostaje w zgodności z wymogami witrażu. Smukłe, dobrze przystosowane do rozmiarów otworu okiennego, wielkie, monumentalne postacie posiadają jasny, celowy kontur. Poszczególne płaszczyzny rozbite są na szereg drobnych szybek przy pomocy podziałów, w których nowoczesny układ sięga swoją genezą tendencji wywodzących się z późnego kubizmu. Podziały te dają możność rozdzielenia płaszczyzny na szereg niewielkich plam barwnych, ruchliwych, współgrających kolorystycznie ${ }^{43}$.

Źródłem inspiracji dla niego była tradycja, a w niej style historyczne, w XX wieku szczególnie mocno działające na wrażliwość i wyobraźnię artystów, czyli sztuka bizantyjska i romańska. Na nich opiera on swoją konwencję formalną. $\mathrm{W}$ jej ramach znajduje indywidualne rozwiązania, zgodne z własną wizją i koncepcją. Adamowi Stalony-Dobrzańskiemu powierzane były przez Urzędy Konserwatorskie i przez Kościół rzymsko-katolicki zamówienia na witraże i polichromie w ważnych dla kultury narodowej obiektach zabytkowych jak: kościół oo. Bernardynów w Radomiu, kościół ewangelicko-augsburski Świętej Trójcy Warszawie, górna cerkiew św. Jana Klimaka i katedra św. Marii Magdaleny w Warszawie oraz katedra św. Jakuba w Nysie.

Opierając się na stylach historycznych podkreślał on prawo artysty do wyboru swoich źródeł inspiracji i ich

\footnotetext{
41 AASP w Krakowie, nr teczki 650/41.

42 Cyt. za H. Blumówna, Witraże Adama Stalony-Dobrzańskiego, [w:] Tygodnik Powszechny, Nr 4, Kraków 1951, s. 5, Biblioteka Uniwersytetu Warszawskiego, mikrofilm nr 17443.

43 M. Gutowski, Trzy wystawy w pałacu sztuki, [w:] Dziennik Polski, nr 71, Kraków 1957, s.6.
}

indywidualnego interpretowania. Jego credo artystyczne podkreślało, że troska i niepokój współczesnych artystów, w poszukiwaniu nowych rozwiązań w sztuce kościelnej, sięgały za daleko, gdyż sprawy zasadniczej wagi i znaczenia rozstrzygnięte zostały już przed wiekami. Według niego dawna sztuka zawsze przemawiała do ludzi z ogromną siłą oraz ożywiała ich uczucia. Można powiedzieć, że swoimi osiągnięciami i rozwojem artystycznym Dobrzański dowiódł słuszności obranej drogi. W określonych ramach swojej koncepcji osiągnął on wielką rozmaitość nastrojów przedstawianych scen, bogactwo typów i charakterów ukazanych postaci. Twórczość Adama Stalony-Dobrzańskiego cechuje uproszczenie kompozycji, redukcja elementów dekoracyjnych, niemal do całkowitego ich wyeliminowania, pogłębienie siły skoncentrowanego wyrazu ${ }^{44}$. Znakomitym przykładem są witraże w cerkwi w Gródku, wypełnione rysunkiem głów siedemdziesięciu apostołów, pełnych dostojeństwa, żywych i niepowtarzalnych. Jest to cecha także i każdej innej jego kompozycji figuralnej. Dzieło artysty było również tematem filmu zrealizowanego przez Wytwórnię Filmów Dokumentalnych w Warszawie. Film o witrażach cerkwi w Gródku Białostockim w reżyserii Jerzego Łomnickiego otrzymał pierwszą nagrodę na Festiwalu Filmów Krótkometrażowych w Wenecji w 1960 roku $^{45}$. Artysta znany był w środowisku plastycznym z wielkiej, bezinteresownej uczynności, wymagającej poświęcenia czasu i energii dla ratowania wartości humanistycznych ${ }^{46}$. Jako społecznik rozwinął szeroką i pełną oddania działalność. Kiedy w 1946 roku powstała Spółdzielnia Artystów Plastyków, Dobrzański był jej kierownikiem. W tym okresie życia włożył wiele zapału, aby w zmienionych warunkach politycznych, stworzyć nowy organizacyjny model wspólnej pracy artystycznej wielu działaczy sztuki użytkowej. Ta idea najbardziej demokratycznie pojętego wspólnego dorobku artystycznego i finansowego przez kilka lat dawała pod jego kierownictwem doskonałe rezultaty, dbając o poziom artystyczny, a więc o przywrócenie wartości zniszczonych w okresie okupacji i o dobro członków w tym trudnym kresie pierwszych lat powojennych. Potem prowadził stałą działalność społeczną, nie tylko na terenie uczelni, ale i Związku Polskich Artystów Plastyków, którego był aktywnym działaczem ${ }^{47}$. Prace artystyczne przy konserwacji i tworzeniu nowych polichromii były również modelem wspólnej pracy, gdzie uczył umiejętności nie tylko warsztatu, ale i umiejętności współpracy. Zespołowo powstawały ukazujące jego talent wielkie dzieła, do których zaliczyć można dekoracje okolicznościowe i dekoracje wnętrz w Przychodni Przeciwgruźliczej w Krakowie, czy w Ośrodku Kultury Plastycznej w Nysie. Działalność dekoracji monumentalnej, związanej z zabytkową architekturą, to liczne prace przy polichromiach i witrażach w Jeleniej Górze, Zawierciu, Nysie i wielu innych miejscowościach ${ }^{48}$. To działalność popularyzatorska dobrej, najbardziej wartościowej

\footnotetext{
44 AASP w Krakowie, nr teczki 650/243.

45 J. Pawlicki, art. cyt., s. 12.

46 AASP w Krakowie, nr teczki 650/263.

47 Tamże, nr teczki 650/244.

48 Tamże, nr teczki 650/244.
} 
sztuki. Na Ziemiach Odzyskanych praca ta miała szczególne znaczenie, przyczyniła się do wzmocnienia osłabionego po drugiej wojnie światowej Prawosławia w Polsce ${ }^{49}$. W nowych, zmienionych warunkach należało budować życie cerkiewne od podstaw, adoptując pozostawione kościoły poewangelickie do wymogów stawianych przez kanony cerkiewne. Niezwykle śmiała wyobraźnia przestrzenna pozwoliła Dobrzańskiemu stworzyć polichromie bardzo doniosłe, wyjątkowe na gruncie polskim. Dlatego też nazywany jest powojennym apostołem kultury prawosławnej w Polsce ${ }^{50}$

Dokonania artystyczne Adama Stalony-Dobrzańskiego pozostają dzisiaj w cieniu twórczości jego ucznia Jerzego Nowosielskiego. Pomimo wielkiego wkładu w rozwój sztuki sakralnej w Polsce, jego nazwisko jest mało znane. Jeszcze za życia mistrza jego sztuka została „̇̇ywcem pogrzebana”. Przyczyn należy szukać w uwarunkowaniach politycznych, w czasie których przyszło żyć artyście. Według wnuka artysty - Jana Pawlickiego, po kilku brutalnych, ale i bezowocnych latach starań nad pozyskaniem go jako cennego w rozgrywkach $\mathrm{z}$ Kościołem agenta bezpieki, komunistyczna władza wydaje ostateczną decyzję o całkowitej izolacji artysty, o pełnym zakazie wystaw i publikacji dotyczących jego twórczości. W 1961 roku, w dniu otwarcia zamknięta została wystawa jego witraży, zorganizowana w słynnym Pałacu Sztuki w Krakowie, a katalog skonfiskowany za „szerzenie treści religijnych”. Wstrzymane zostało nadanie artyście tytułu profesora Akademii Sztuk Pięknych w Krakowie, gdzie już do emerytury zaledwie jako docent prowadził dyplomującą i międzywydziałową katedrę liternictwa. Ale co najważniejsze, poprzez podległe władzy Urzędy Konserwatorów Zabytków, wychodzi tajne rozporządzenie - zakaz akceptacji do zabytkowych kościołów figuralnych, kanonicznych kompozycji sakralnych. I w ten sposób ten wielki artysta otrzymał karę, którą miało być, jak podkreśla jego wnuk,całkowite zapomnienie. ${ }^{51}$.

\section{Ekumenizm prof. Adama Stalony-Dobrzańskiego ${ }^{52}$}

W Tygodniku Powszechnym, który ukazał się 31 marca 1985 roku, umieszczony został nekrolog o następującej treści: „dnia 22 marca 1985 roku zmarł doc. Adam Stalony-Dobrzański, wieloletni kierownik katedry liternictwa Akademii Sztuk Pięknych w Krakowie. Znany ze swych

\footnotetext{
49 A. Rydzanicz, W przestrzeniach życia, [w:] Przegląd prawosławny, nr 6 (300), czerwiec 2010, s. 27.

50 Architektura $i$ wyposażenie, http://www.jeleniagora.cerkiew.pl/html/ architektura.html, [12.11.2010].

51 J. Pawlicki, art. cyt., s. 12.

$\mathrm{Na}$ podstawie wywiadu przeprowadzonego przeze mnie $\mathrm{z}$ Janem Pawlickim w grudniu 2010 roku w Wieliczce. Jest to próba opisania profesora Adama Stalony-Dobrzańskiego przez jego wnuka. Muszę dodać, że miałem ogromne trudności z wychwyceniem istotnych informacji ze względu na emocjonalne potraktowanie tematu przez Jana Pawlickiego, syna córki prof. Adama Stalony-Dobrzańskiego.
}

witraży i polichromii. Gorący zwolennik Ekumenii”53. Zastanawiające jest, dlaczego w nekrologu tak mocno zaakcentowany został ekumenizm, do tego stopnia, że słowo napisano z wielkiej litery. Powyższe wyjaśnia wnuk artysty, pan Jan Pawlicki.

Adam Stalony-Dobrzański był wielkim ekumenistą. Złożyło się na to parę czynników. Pierwszy z nich to samo pochodzenie artysty. Był człowiekiem dwóch kultur, polskiej po ojcu i ukraińskiej po matce. Wychowanie wyniesione $\mathrm{z}$ rodzinnego domu powodowało, że zawsze był otwarty na ludzi. Należy dodać, iż ojciec Dobrzańskiego był szlachcicem polskim, a w rodzinie przechowywane były jeszcze tradycje rycerstwa spod Grunwaldu, na którego to polach Dobrzańscy otrzymali przydomki szlacheckie za odwagę i męstwo. Samo już nazwisko miało więc głębokie podłoże historyczne sięgające 1410 roku. Stalony jak stal, która się niczemu nie poddaje. W prof. Dobrzańskim było to męstwo polskiej szlachty takiej, która stawała zawsze do boju za ojczyznę. Dobrzańscy znaleźli się na wschodzie za powstanie styczniowe. Jego ojciec Feliks Stalony-Dobrzański poznał Ukrainkę Annę Kowalenko starowierskiego wyznania. Wychowany został w Prawosławiu. Matka przekazała synowi mentalność oraz żarliwą duchowość staroobrzędowców, świadomość ikony, która później w jego domu stanowiła centrum. Zawsze wieczorem modlił się. Ikony były wszędzie.

Ten człowiek o ogromnej kulturze osobistej, będąc jednocześnie Polakiem i żarliwym wyznawcą Prawosławia, był ukształtowany przez Akademię Sztuk Pięknych w Krakowie, w czasach jej największej świetności, w międzywojennym okresie, kiedy wypuszczano stamtąd największych geniuszy. Uformowała go elita kulturalna Polski, najwyższej klasy: uczniowie Matejki i Wyspiańskiego. Błyszczał więc na salonach. Był jednym z bardzo nielicznych, który wychodząc z salonu, mógł i chciał współpracować z Kościołem w pełni. Okazał się jedynym, który mógł zafascynować ludzi Kościoła otwartych na tematy sztuki. A tacy się pojawili w związku z ogromną katastrofą Kościoła po wojnie. W sytuacji ucisku Kościół potrzebował nowego otwarcia na ludzi kultury. Takim człowiekiem był w Krakowie Dobrzański. Jako wielki malarz miał niezwykły wpływ na ludzi, ponieważ był człowiekiem ogromnej kultury osobistej, również nieco antycznej. Obracał się w najwyższych sferach, a przy tym był człowiekiem bardzo błyskotliwym. Repatriował do Polski z imperium rosyjskiego, będąc jednocześnie polskim szlachcicem po ojcu. Do kraju przyjechał człowiek najwyższej kultury bycia. Był kwiatem salonów. A jednocześnie, ponieważ to okres ucisku Kościoła, Kościół jakby zbliżył się do owych salonów artystycznych. Należy pamiętać, że sfery te nie były sobie bliskie,również w Polsce międzywojennej. Okres kiedy były one blisko siebie, to był czas Młodej Polski, czas Wyspiańskiego. To właśnie w Krakowie Dobrzański trafił na przyszłego papieża, kardynała Karola Wojtyłę. I tegoż właśnie przyszłego papieża nauczył o wielkości Prawosławia. To dlatego później cała droga, starania ekume-

\footnotetext{
53 Cyt. za Nekrolog, [w:] Tygodnik Powszechny, Nr 13, Kraków 1985, s. 7
} 
niczne na wschód papieża Jana Pawła II uznane są przez Jana Pawlickiego, za konsekwencję bliskich kontaktów z prof. Adamem Stalony-Dobrzańskim, którego zresztą bardzo promował. Siedem kościołów w diecezji krakowskiej zostało wymalowanych przez Dobrzańskiego właśnie na polecenie Jana Pawła II, kiedy był jeszcze kardynałem w Krakowie. Ta współpraca była też przyczyną nieszczęścia Dobrzańskiego, który odmówił współpracy z UB. To spowodowało karę, , którą było „całkowite zapomnienie”, co mocno podkreśla Jan Pawlicki. Na dowód przytacza zapis cenzorski z 1963 roku o całkowitym odsunięciu jego sztuki od jakiejkolwiek informacji. Nie można było pisać o nim w prasie. I w ten sposób ten wielki człowiek, staje się artystą bez publiczności Nie mógł wówczas zorganizować żadnej wystawy. Malował w kościołach, które nie były zabytkami. Bo tam, gdzie były zabytkowe kościoły, znowu konserwatorzy wojewódzcy, którzy w pewnym sensie byli zależni od urzędu bezpieczeństwa, mieli za zadanie ograniczać Kościól, a w tym nie dopuścić do realizacji wyobrażeń w ogóle figuratywnych. Tak bardzo prof. Dobrzański, według Jana Pawlickiego, „wystraszył” ówczesną władzę swoimi dziełami. Artysta był ekumenistą bardzo otwartym, ale w bardzo dziwnej sytuacji i układzie. Dla nas, zaznacza Jan Pawlicki, dla prawosławnych ekumenizm jest w pewnym sensie ogromnym zagrożeniem. Traktujemy go dziś, jako jedną z dróg penetracji katolicyzmu. Wówczas była to sytuacja odwrotna, gdyż to on wtedy zdominował Kościół. Ekumenizm był narzędziem jego władzy nad Kościołem, a nie władzy Kościoła nad nim. Prawosławie, nie wiadomo dlaczego, obawia się ekumenizmu, jakby występowało z pozycji słabszej, ze względu na słabszą organizacje. Ale gdyby narzuciło ekumenizm w przestrzeniach takich jak sztuka, ikona, to skorzystałoby na nim. Zmusiłoby Kościół do wsłuchania się w głos Prawosławia. Na tym polega tajemnica „sukcesu” ekumenicznego Stalony -Dobrzańskiego, który potrafił przekuć naa własny sukces to, co wydawało się zagrożeniem. Przyciągał do siebie wielu, włącznie z przyszłym papieżem Janem Pawłem II. Nie interesowały go sprawy finansowe, podobnie jak temat prymatu papieża. Ten ostatni nie był mu jednak do końca obojętny, Jan Pawlicki pamięta, że również kwestia Kościoła greckokatolickiego dla Adama Stalony-Dobrzańskiego były bardzo drażliwa, pojmując ją jako krzywdę dla Kościoła prawosławnego. Natomiast zajmował się ekumenią na polu sztuki, gdzie po prostu wprowadzał Bizancjum w przestrzeń Kościoła, zawsze z pełnym sukcesem.

Dobrzański bardzo często mawiał, że u chrześcijan nie ma ani Greka, ani Żyda. Według niego Kościół uwikłany w nacjonalizm to największa katastrofa. Kościól jako jeszcze jeden z urzędów cesarskich, bez względu na to czy prawosławny na wschodzie, czy katolicki lub protestancki na zachodzie, był jednym z urzędów władzy cesarskiej. Były podporządkowane władzy cesarskiej jako urzędy i wykonywały pracę na rzecz nacjonalizmów. Niemiecka Matka Boska „tłukła się" na śmierć i życie z rosyjską Matką Boską. Tołstoj pisał, że deską błogosławią biskupi ludzi na wojnę, na śmierć. Wnuk profesora patrzy na to z punktu widzenia Ewangelii, a nie przeciwnika Ewange- lii. Jest to jedna z największych zbrodni, jaką uczyniono chrześcijaństwu, czyli podzielenie na nacjonalistyczne obozy, zwalczjące się obozy. Był to wstyd dla całego świata. I Dobrzański dobrze o tym wiedział, mając ojca katolika i matkę prawosławną. Miał w tym zakresie bardzo nieprzyjemne doświadczenia. Gdy w czasie wojny umarła mu matka, żona miejscowego sędziego w Miechowie przyjechał z trumną aby pochować ją na miechowskim cmentarzu. Ksiądz katolicki na ten widok odpowiedział mu: „proszę zabrać tę trumnę, bo zadzwonię na gestapo, gdyż pan chce sprofanować katolicki cmentarz". Dzisiaj jest to niewyobrażalne. Warto przy tym dodać, że matka była żoną sędziego, który wykupił grób. Dobrzański miał doświadczenia, po których mógł znienawidzić katolicyzm fundamentalnie. Natomiast on uznał to jako „wybryk natury". Ten wybitny artysta był objawieniem. Swoim niesamowitym, niezwykłym geniuszem pokazał, że piękno jest ekumeniczne i nie podlega narodowościowym podziałom. Piękno jest językiem Boga. Język Boga zawsze będzie ekumeniczny. Piękno wyobrażeń Dobrzańskiego było zatem ekumeniczne. I to ono rozpraszało wszelkie uprzedzenia. Artysta ten był ekumenistą pomiędzy dwoma wrogimi sobie przestrzeniami: katolicką i prawosławną. Dobrzański odniósł na tym polu pełen sukces. Jego wnuk ma nadzieję, że teraz przyszedł czas renesansu tego człowieka.

Ekumenizm Dobrzyńskiego dotyka także jego twórczości malarskiej. Stworzył on koniunkcję zarówno wschodu jak i zachodu oraz współczesności i tradycji poprzez witraż, który jest czystą techniką zachodnią. Ale nie wykorzystał go jako narzędzia, które przeniósł dokładnie na układ kanonu ikony. Zachował go w jego surowej, romańskiej formule. Nałożył na nią i zmieszał z przedikonokalstyczną ikoną, nie z czasów renesansu paleologów, ale z ikoną wcześniejszą. A dlaczego mógł to zrobić? Ponieważ tak naprawdę romańszczyzna zachodnia była bardzo preikonoklastyczna. Nie dotarła tam wojna ikonoduli i ikonoklastów z Bizancjum, gdyż było za daleko. Jej elementy pojawily się później, więc witraż romański, czy wczesnogotycki jest bardzo preikonoklastyczny. Dobrzański potrafił znaleźć wspólny mianownik i połączyć zarówno romańszczyznę jak i wczesne doikonoklastyczne Bizancjum. Przez to jego sztuka jest zjawiskiem ekumenicznym. Zjawiskiem koniunkcji czterech elementów: tradycji i nowoczesności, wschodu i zachodu. Artysty który na raz połączyłby tyle elementów w swojej sztuce nie ma i nie było w całej sztuce europejskiej, szczególnie w dziedzinie witrażu.

Zdaniem Jana Pawlickiego artysta był człowiekiem niezwykle energicznym, dlatego też chciał zmieniać pole swoich działań. Był trochę jak wcześni apostołowie, którzy nie mówili do swoich, ale do obcych. Dobrzański był w świetnej sytuacji, gdyż pozostając w Krakowie, środowisku innym, obcym, czasami wrogim, miał ogromną motywację do działania. Prowadził bowiem dialog, przekonywał i walczył. Pozwoliło to na otwarcie się jego samego ale także jego twórczości Ekumenizm był bowiem treścią życia artysty. 


\section{Systematyka dorobku artystycznego}

Już w czasie studiów Adam Stalony-Dobrzański kilkakrotnie otrzymywał pochwały i wyróżnienia. W roku 1929 jego rysunki znalazły się na Wystawie Sztuki Powszechnej Wystawy Krajowej w dziale „Piękna Książka” w Poznaniu. W roku 1931 został nagrodzony pochwałą Akademii Sztuk Pięknych w zakresie grafiki i liternictwa, a w roku następnym zaprojektował okładkę czasopisma „Sztuki Piękne”. Malował też w tym czasie akwarele. W roku 1933 współpracował z Janem Cichoniem przy odkryciu i konserwacji średniowiecznej polichromii stropu kościoła drewnianego w Harklowej, na Podhalu. W roku następnym pracował przy konserwacji gotyckich tryptyków z kościołów w Harklowej i Łopusznej, a także odnawiał gotycki krucyfiks w kościele parafialnym w Turku. W roku 1935 wspólnie z Ludwikiem Gardowskim i Stanisławem Westwalewiczem wziął udział w konkursie na projekt polichromii i ołtarza głównego w kościele Mariackim w Chełmie Lubelskim. Otrzymali na nim IV nagrodę ${ }^{54}$. W 1936 roku dostał wraz z Ludwikiem Gardowskim III nagrodę w konkursie architektoniczno-urbanistycznym na projekt otoczenia kopca Józefa Piłsudskiego na Sowińcu w Krakowie ${ }^{55}$. Współpracował także przy wykonaniu polichromii kościelnych w Porębie Górnej w 1936 roku i w Dobromilu w 1939 roku. Projektował również plakaty, między innymi w roku 1934 dla wystawy sztuki polskiej organizowanej przez Towarzystwo Szerzenia Sztuki Polskiej wśród Obcych w Tallinie oraz w roku 1939 na targi zielarskie w Wilnie. W czasie wojny wykonywał różne prace dla kościołów. U Bernardynów w Radomiu kontynuował rozpoczętą w roku 1938 restaurację wyposażenia wnętrza, między innymi gotyckich figur pasji ołtarza głównego. Z Wiktorem Langnerem w 1941 roku stworzył polichromię kościoła, która obecnie jest zamalowana oraz w roku 1943 w takim samym składzie, polichromię kościoła parafialnego w Gorlicach ${ }^{56}$.

Po drugiej wojnie światowej Adam Stalony-Dobrzański rozwinął bogatą twórczość artystyczną w dziedzinie monumentalnego malarstwa sakralnego. Projektował polichromie i witraże do świątyń katolickich, prawosławnych i ewangelicko-augsburskich. Zrealizował jeden witraż na zamówienie Polonii Amerykańskiej i jeden do cerkwi Neseber w Bułgarii ${ }^{57}$. Jego witraże znalazły się również $\mathrm{w}$ rezydencji metropolity prawosławnego w Warszawie. Część z nich usytuowanych jest obecnie w drzwiach kaplicy Prawosławnego Seminarium Duchownego w Warszawie $^{58}$. W roku 1945, wspólnie z Ludwikiem Gardowskim, wykonał malowidła w kaplicy błogosławionego Szymona z Lipnicy w kościele Bernardynów w Krakowie, przedsta-

\footnotetext{
Polskie życie artystyczne $w$ latach 1915-1939, Wrocław, Warszawa, Kraków, Gdański 1974, s. 337.

55 Tamże, s. 508.

56 E. Dwornik-Gutowska, dz. cyt., s. 497.

57 AASP w Krakowie, nr teczki 650/259.

58 Wcześniej znajdowały się w siedzibie Prawosławnego Metropolity w Warszawie.
}

wiające między innymi klasztory bernardyńskie w Polsce ${ }^{59}$. W latach 1946-1947 dokończył, rozpoczętą w roku 1943, polichromię wnętrza kościoła parafialnego w Bobinie kolo Proszowic. Około roku 1946 powstał jeden z pierwszych witraży Stalony-Dobrzańskiego, wspólny z Ludwikiem Gardowskim, przedstawiający św. Barbarę, patronkę górników. Został on umieszczony w holu gmachu głównego Akademii Górniczo Hutniczej w Krakowie. Usunięty został w roku 1952. Przechowywany był w kościele jezuickim św. Barbary. Na swoje miejsce powrócił dopiero w roku 1981. Artysta tworzył także większe zespoły witraży. W latach 1950-1956 wykonał witraże dla kościoła parafialnego w Trzebownisku koło Rzeszowa. W latach 1950-1964 dla kościoła parafialnego w Zawierciu, w 1atach 1953-1955 dla cerkwi w Gródku, w latach 1953-1961 w kościele parafialnym w Rozwadowie koło Tarnobrzegu. W latach 19581967 w odbudowanej po zniszczeniach wojennych katedrze w Nysie. Tam wykonał 232 pola w monumentalnych oknach $^{60}$. Przed rokiem 1964 dla kościoła ewangelickoaugsburskiego pod wezwaniem Świętej Trójcy na pl. Małachowskiego w Warszawie. W 1atach 1969-1970 w Tenczynku. W latach 1973-1978 w Kozach koło Bielska-Białej. W roku 1978 w Szczyrku. W roku 1979 w Wilkowicach koło Jarosławia. W latach 1976-1981 w Skorogoszczy koło Niemodlina. Projektował też mozaiki ceramiczne w dekoracjach zewnętrznych, między innymi dla kościoła w Gołczy koło Miechowa w 1949 roku. Po latach, w 1982 roku w czasie zjazdu uczniów z okazji 55-lecia matury, był inicjatorem odnowienia kaplicy na cmentarzu w Miechowie ${ }^{61}$.

Witraże Adama Stalony-Dobrzańskiego wykonywały warsztaty krakowskie: zakład S. G Żeleńskiego, pracownia Romana Ryniewicza i pracownia Braci Paczków. Obok doskonałego opanowania rzemiosła i wyczucia specyfiki gatunku, witraże i polichromie artysty odznaczają się oryginalnym, syntetycznym traktowaniem monumentalnej formy, nawiązującej do sztuki romańskiej i bizantyńskiej, przy bardzo nowoczesnym geometrycznym uproszczeniu. Zespoły o określonej tematyce religijnej są uzupełnione objaśniającymi tekstami biblijnymi, w których Stalony-Dobrzański stosował, dekoracyjnie wkomponowane w całość, liternictwo gotyckie lub cyrylicę. Jako sygnatury artysta używał splecionych liter swojego imienia i nazwiska: ASD w formie gotyckiego maswerku, w kształcie łodzi Piotrowej wpisanej w grecki, równoramienny krzyż.

W latach 1951-1956 wspólnie ze swoim uczniem Jerzym Nowosielskim wykonał polichromię cerkwi pod wezwaniem Narodzenia Najświętszej Marii Panny w Gródku koło Białegostoku. W 1953 roku współpracował z tymże artystą przy tworzeniu polichromii cerkwi w Jeleniej Górze i już nieistniejącej cerkwi w Dojlidach ${ }^{62}$. Na jej miejscu stanęła nowa świątynia. Również z Jerzym Nowosielskim

\footnotetext{
59 Katalog zabytków sztuki w Polsce, tom IV, część 4, Warszawa 1987, s. 12 .

60 Nowe witraże w Nysie, [w:] Tygodnik powszechny, Kraków 1958, nr 49 (515), s. 6 .

61 E. Dwornik-Gutowska, dz. cyt., s. 498.

62 M. Kitowska-Łysiak, Jerzy Nowosielski, http://www.culture.pl/pl/ culture/artykuly/os_nowosielski_jerzy [12.11.2010].
} 
w 1955 roku stworzył polichromię cerkwi św. Mikołaja w Michałowie. W 1963 ukończył, również z Jerzym Nowosielskim oraz Bolesławem Oleszko, polichromię cerkwi Przemienienia Pańskiego na Świętej Górze Grabarce. Niestety, na Grabarce nie możemy już podziwiać pracy Adama Stalony-Dobrzańskiego i jego zespołu. Polichromia spłonęła wraz z cerkwią w 1990 roku $^{63}$. Przed rokiem 1964 zaprojektował witraże w prawosławnej Katedrze Narodzenia Przenajświętszej Bogarodzicy we Wrocławiu, a w roku 1964 mozaikę ceramiczną zewnętrzną w tejże świątyni. W latach 1964-1965 stworzył polichromię cerkwi św. Michała Archanioła w Przemkowie na Ziemiach Odzyskanych. Równolegle w latach 1965-1966 wykonał polichromię w kościele św. Michała Archanioła w Nowej Soli. W prawosławnej katedrze metropolitalnej św. Marii Magdaleny w Warszawie, w latach 1968-1969, gdy zwierzchnikiem cerkwi prawosławnej był metropolita Stefan (Rudyk), brał udział w konkursie na projekt renowacji świątyni. Wszystkie nadesłane projekty odbiegały od wcześniejszego planu wnętrza. Ostatecznie zapadła decyzja, aby zrekonstruować freski zgodnie z ich stanem pierwotnym. Jednakże w 1977 roku umieszczono witraż jego autorstwa nad okratowanymi, wewnętrznymi drzwiami do katedry, przedstawiający objawienie się św. Marii Magdalenie zmartwychwstałego Chrystusa ${ }^{64}$. Do tego soboru zaprojektował ponadto mozaikę ceramiczną w dekoracji zewnętrznej, przedstawiającą św. Marię Magdalenę. W latach siedemdziesiątych w cerkwi Św. Mikołaja Cudotwórcy w Poznaniu wykonał witraż na chórze nad przedsionkiem, przedstawiający Matkę Bożą Włodzimierską wraz ze św. Mikołajem Cudotwórcą - patronem cerkwi i św. Hiobem Poczajowskim ${ }^{65}$. W 1976 roku zrealizował polichromię w cerkwi św. św. Cyryla i Metodego we Wrocławiu na Piaskach. W roku 1978 zaprojektował polichromię górnej cerkwi św. Jana Klimaka na Woli w Warszawie oraz witraż w tejże świątyni. W soborze Świętej Trójcy w Hajnówce, który powstał w latach 1973-1982, wykonał jedynie wstępny projekt witraży ${ }^{66}$. Pozostawił niezrealizowane projekty polichromii cerkwi w Drohiczynie, Jałówce i Morochowie ${ }^{67}$.

Po wojnie Adam Stalony-Dobrzański w dalszym ciągu tworzył grafikę, zwłaszcza książkową i plakatową, wykonywał afisze liternicze i opracowania graficzne swoich i innych wystaw np. „Wystawy pośmiertnej prac polskich artystów plastyków zamordowanych przez Niemców w Krakowie w 1945 roku” oraz „Wystawy Oskarżamy hitlerowców o zbrodnię...” w Krakowie w 1965 roku. Opracował graficznie projekt okładki, obwolutę i układ ilustracji do wydawnictwa albumowego Jana Matejki: Ubiory w Polsce 1200-1795, wydanego w Krakowie w 1967 roku, Poczet królów polskich wydanego w Krakowie w 1969 roku, a tak-

\footnotetext{
63 A. Radziukiewicz, Grabarka. 300 lat cudu na Świętej Górze, [b.m.w.], [b.r.w.], s.38-42.

${ }^{64}$ Katedra Równej Apostołom św. Marii Magdaleny w Warszawie, Białystok [b. r. w.], s. 23-24.

${ }^{65}$ A. Grygorowicz, Architektura świątyń prawosławnych $w$ Polsce, [w:] Prawosławie. Światło wiary i zdrój doświadczenia, Lublin 1999, s. 342-343. ${ }^{66}$ A. Rydzanicz, W przestrzeniach życia (część II), [w:] Przegląd prawosławny, nr 4(298), kwiecień 2010, s. 26-29.

67 AASP w Krakowie, nr teczki 650/42.
}

że książki Stefana Wyszyńskiego w światłach Tysiąclecia wydanej w Krakowie w 1961 roku i Karola Wojtyły Miłość i odpowiedzialność wydanej w Krakowie w 1962 roku. Według jego projektów literniczych powstały tablice pamiątkowe w Krakowie: przysięgi Tadeusza Kościuszki na Rynku Głównym, pamięci pomordowanych w czasie wojny artystów plastyków w holu budynku Akademii Sztuk Pięknych, dawne Muzeum Przemysłowe przy ul. Smoleńsk 9 i tablica W. I. Lenina w Muzeum Lenina przy ul.Topolowej 5. Stalony -Dobrzański zajmował się również projektowaniem haftów i szat liturgicznych dla klasztoru Reformatów w Krakowie, sztandarów w Akademii Górniczo-Hutniczej, Centrali Przemysłu Naftowego i Instalu ${ }^{68}$. Ponadto zaprojektował dla Polskiego Autokefalicznego Kościoła Prawosławnego order Marii Magdaleny i znak PAKP oraz pierwszą stronę Wiadomości PAKP - jeden z pierwszych numerów.

Monumentalna sztuka Stalony-Dobrzańskiego rzadko gościła na wystawach, między innymi ze względu na trudności techniczne ich organizowania. W roku 1949 wziął udział we współorganizowanej przez siebie wystawie „Sztuka potrzebna każdemu”. Witraże i ich projekty, fotografie oraz diapozytywy pokazywał na I, II, i III Ogólnopolskich Wystawach Współczesnej Sztuki Religijnej w roku 1959, urządzonej przez Klub Inteligencji Katolickiej, w dolnym kościele Świętego Krzyża w Warszawie, w roku 1961 urządzonej przez Klub Inteligencji Katolickiej i wydawnictwo Znak, w krużgankach klasztoru Dominikanów w Krakowie oraz w roku 1964 zorganizowanej przez wydawnictwo Znak, w kościele NMP na Piasku we Wrocławiu $^{69}$. Indywidualne wystawy Adama Stalony-Dobrzańskiego odbywały się: od 24 lutego do 15 marca 1957 roku w Towarzystwie Przyjaciół Sztuk Pięknych w Krakowie w Pałacu Sztuki ${ }^{70}$, eksponowana następnie w salach muzeum w Przemyślu, od grudnia 1960 roku do stycznia 1961 roku zorganizowana przez Związek Polskich Artystów Plastyków i Centralne Biuro Wystaw Artystycznych w Katowicach oraz Towarzystwo Przyjaciół Sztuk Pięknych w Krakowie $^{71}$. Ta ostatnia wystawa została ze względu na sakralną tematykę zamknięta przez Urząd Kontroli Prasy, a katalog skonfiskowano. Wtedy też Stalony-Dobrzański został objęty zakazem publikacji, wystaw oraz $\mathrm{w}$ związku z propozycją współpracy złożonej mu przez wielką pracownię witraży w USA wyjazdów i wysyłania swych dzieł za granicę. W roku 1981 urządzono jego kameralną wystawę w Klubie Politechniki. Krakowskiej ${ }^{72}$.

Adam Stalony-Dobrzański czynnie uczestniczył w pracach różnych stowarzyszeń. W roku 1945 brał udział w reaktywowaniu Związku Polskich Artystów Plastyków, którego był członkiem. Był współzałożycielem Spółdzielni Pracy Artystów Plastyków, której osiągnięcia zostały zaprezentowane w roku 1949 na wystawie „Sztuka potrzebna każdemu”

\footnotetext{
68 E. Dwornik-Gutowska, dz. cyt., s. 498.

69 III Wystawa Współczesnej Sztuki Religijnej, Wrocław 1964, nr 12 (126), s. $1499-1506$.

70 Katalog wystawy kartonów witraży Adama Stalony-Dobrzańskiego [1950-1956], dz. cyt., s. 2-3.

71 Wystawa witraży, dz. cyt., s.4-9.

72 E. Dwornik-Gutowska, dz. cyt., s. 498-499.
} 
w Pałacu Sztuki w Krakowie. Pełnił funkcję rzeczoznawcy do spraw malarstwa i konserwacji w Ministerstwie Kultury i Sztuki oraz był członkiem komisji Izby Rzemieślniczej dla Witrażystów. Był działaczem Związku Nauczycielstwa Polskiego i Frontu Jedności Narodowej. Działał także w Towarzystwie Przyjaciół Sztuk Pięknych w Krakowie. Należał do Zarządu Głównego Chrześcijańskiego Stowarzyszenia
Społecznego w Warszawie. Był jednym z pionierów ekumenizmu w Polsce. Zasiadał jako radca świecki w Radzie Metropolitalnej PAKP przy metropolicie Bazylim (Doroszkiewiczu), a także w radzie artystycznej przy metropolicie krakowskim kardynale Wojtyle ${ }^{73}$.

73 Tamże, s. 499.

\section{Bibliografia}

175 lat nauczania malarstwa, rzeźby i grafiki w krakowskiej ASP, Kraków 1994.

Blumówna H., Witraże Adama Stalony-Dobrzańskiego, [w:] Tygodnik Powszechny, Nr 4, Kraków 1951, Biblioteka Uniwersytetu Warszawskiego, mikrofilm nr 17443.

Chrzanowski T., Z krakowskich wystaw, [w:] Tygodnik Powszechny, Nr 15, Kraków 1961.

Dobrowolski T., Nowoczesne malarstwo polskie, tom III, Wrocław -Warszawa-Kraków 1964.

Doc. Adam Stalony-Dobrzański, [w:] Dziennik Polski, Nr 74, Kraków 1985.

Dwornik-Gutowska, E. Stalony-Dobrzański Adam, Polski Słownik Biograficzny, Tom XLI, Warszawa-Kraków 2002.

Grygorowicz A., Architektura świątyń prawosławnych $w$ Polsce, [w:] Prawosławie. Światło wiary i zdrój doświadczenia, Lublin 1999.

Gutowski M., Trzy wystawy w pałacu sztuki, [w:] Dziennik Polski, nr 71, Kraków 1957.

Katedra Równej Apostołom św. Marii Magdaleny w Warszawie, Białystok [b. r. w.].

Marcinkowski R., ks. bp, Kronika religijna. Śp. prof. Adam Stalo$n y$-Dobrzański [w:] Tygodnik Powszechny, Nr 14, Kraków 1985.

Nekrolog, [w:] Tygodnik Powszechny, Nr 13, Kraków 1985.

Nekrolog, Dziennik Polski, Nr 74, Kraków 1985.

Nowe witraże w Nysie, [w:] Tygodnik powszechny, Kraków 1958, nr 49 (515).

Pawlicki J., Stworzenie światła: witraże Adama Stalony-Dobrzańskiego, [w:] Zabytki, Nr 7(22), Warszawa 2007.

Polskie życie artystyczne w latach 1915-1939, Wrocław, Warszawa, Kraków, Gdański 1974.

Radziukiewicz A., Grabarka. 300 lat cudu na Świętej Górze, [b.m.w.], [b.r.w.].

Rydzanicz A, W przestrzeniach życia, [w:] Przegląd prawosławny, nr 6 (300), czerwiec 2010.

Rydzanicz A., W przestrzeniach życia (czesść II), [w:] Przegląd prawosławny, nr 4(298), kwiecień 2010.
Skrzynecki P., Witraże w pałacu sztuki, [w:] Echo Krakowa, Nr 68, Kraków 1957.

Stalony-Dobrzańska A., Błękit, [w:] Wiadomości PAKP, nr 4, Warszawa 1979.

\section{Źródła obcojęzyczne}

Павлицький Я., Адам Сталони Добжанський або Сотворіння Світла, [в:] Культура, Нр. 43, 2009.

\section{Katalogi}

Wystawa witraży. Adam Stalony-Dobrzański 1950-1960, Kraków XII 1960/I 1961.

Katalog wystawy kartonów witraży Adama Stalony-Dobrzańskiego [1950-1956], Towarzystwo Przyjaciół Sztuk Pięknych, Kraków 1957.

III Wystawa Współczesnej Sztuki Religijnej, Wrocław 1964, nr 12 (126).

Katalog zabytków sztuki w Polsce, tom IV, część 4, Warszawa 1987. Wystawy jubileuszowe 150-lecia Akademii Sztuk Pięknych w Krakowie, Kraków 1969.

\section{Archiwa}

Archiwum Akademii Sztuk Pięknych w Krakowie, akta osobowe prof. Adama Stalony-Dobrzańskiego, 1947-1975, nr teczki 650 .

Wywiady

Wywiad przeprowadzony przeze mnie z Janem Pawlickim, Wieliczka, XII 2010.

\section{Źródła internetowe}

Architektura i wyposażenie, http://www.jeleniagora.cerkiew.pl/ html/architektura.html, [12.11.2010].

Dobrzański Adam Stalony, za http://pracownia.michalowo.eu/ znani-ludzie-15 [16.06.2014].

Kitowska-Łysiak M. , Jerzy Nowosielski, http://www.culture.pl/pl/ culture/artykuly/os_nowosielski_jerzy [12.11.2010]. 